\title{
Re-Defining Unaccompanied and Separated Children in Russia
}

\section{目 Natalya Kravchuk}

Research Fellow, Institute of Scientific Information for Social Sciences, Russian Academy of Sciences; associate professor, International Law Department, Russian State University of Justice, Candidate of Juridical Sciences. Address: 15 Krzhizhanovskogo Str., Moscow 117292, Russia. E-mail: natkravchuk@mail.ru

\begin{abstract}
㫜目 Abstract
The notion "unaccompanied and separated children" was introduced by the UN Convention on the rights of the child. It is widely used by both international human rights community and governmental bodies of various countries in regulation of treatment of the specific vulnerable group of children. The notion, which initially aimed to address specific needs of children-refugees, gradually evaluated and presently refers to children outside of country of their origin who are not being cared for by a responsible adult or who are with family members that are not their primary caregivers, including illegal migrants. Certain scope of rights and guarantees is attributed to the notion to address their needs that should be determined using the best interests of the child principle. Russia does not use the notion developed on the international level in the national law in its human rights meaning. It was literary translated and adjusted to national perceptions (redefined). The content of the term used to define the group in Russia - "children deprived of a parental care" (deti, ostavshiyesya bez roditelskogo popecheniya) is similar but not equal. It allows to strip children of the guarantees attributed to the notion "unaccompanied and separated children" by the international treaty and to consider unaccompanied and separated children within the contexts of "violation by parents of their parental rights" and "migration". The change of the focus brings along a perversion of the understanding of the best interests of these children and measures the state is obliged to undertake to protect them. Moreover, it puts all the blame regarding the situation of children on their parents, leaving the state a secondary role.
\end{abstract}

\section{0-4目 Keywords}

unaccompanied and separated children; UN Convention on the rights of the child; notion; children; deprived of a parental care; child rights; best interests of the child; Russia; migrants.

JEL: K 33, K36;

DOI: 10.17323/2072-8166.2016.2.36.44

Citation: Kravchuk N. (2016) Re-Defining Unaccompanied and Separated Children in Russia. Pravo. Zhurnal Vysshey shkoly ekonomiki, no 2, pp. 36-44 (in English).

\section{Introduction}

The notion "unaccompanied and separated children" introduced by the UN Convention on the Rights of the Child is widely applied by both the international human rights community and governmental bodies of various countries in regulating the treatment of a specific vulnerable group of children.

In this article I aim to show that the notion and its meaning, which was formed by providing safeguards for these children, are essential for their protection. I argue that by adopting a 
different meaning to it following the literal translation and adjustment to national perceptions (re-defining it) Russia deprives them of the guarantees attributed to the notion "unaccompanied and separated children" by the aforesaid international treaty.

With this in view, I describe the process of the construction of the meaning of the notion on the international level, and how it was substituted by terms with a similar but not equal meaning that exist in Russian law. The content of the term used to define the group in Russia - "children deprived of parental care" (deti, ostavshiyesya bez roditelskogo popecheniya) allows considering unaccompanied and separated children within the contexts of "violation by parents of their parental rights" and "migration". The change of focus results in a perversion of the understanding of the best interests of these children, and measures what the state is obliged to undertake to protect them.

\section{"Unaccompanied and Separated Children": the Group and Rights to Which it is Entitled}

\section{Who are these children?}

The notion of "unaccompanied and separated children" was introduced by the UN Convention on the Rights of the Child (1989) to address specific needs of child refugees. It is noted that about half of the world's 10 million refugees are children. The problem of migration is thus not regional but truly global. Almost every Concluding Observation by the Committee on the Rights of the Child (CRC) ${ }^{1}$ has a section on the country's treatment of refugee children ${ }^{2}$.

According to the Art.22 of the Convention:

1. States Parties shall take appropriate measures to ensure that a child who is seeking refugee status or who is considered a refugee in accordance with applicable international or domestic law and procedures shall, whether unaccompanied or accompanied by his or her parents or by any other person, receive appropriate protection and humanitarian assistance in the enjoyment of applicable rights set forth in the present Convention and in other international human rights or humanitarian instruments to which the said States are Parties.

2. For this purpose, States Parties shall ..... protect and assist such a child and to trace the parents or other members of the family of any refugee child in order to obtain information necessary for reunification with his or her family. In cases where no parents or other members of the family can be found, the child shall be accorded the same protection as any other child permanently or temporarily deprived of his or her family environment for any reason, as set forth in the present Convention. Though initially it was envisaged that Article 22 of the CRC would not cover migrant children who are not refugees, including many of the world's unaccompanied children that are so-called economic migrants fleeing poverty and lack of opportunity rather than persecution, the initial meaning of the notion in question received a new interpretation with time. It presently refers to children who are not being cared for by a responsible adult, or to children who are with family members that are not their primary caregivers. Such children primarily include refugees, trafficked children and children in search of economic opportunities; they are often exposed to exploitation, abuse, persecution and discrimination and thus

${ }^{1}$ The Committee on the Rights of the Child is the body that monitors implementation of the Convention on the Rights of the Child by its State parties. The Committee examines a State's report and addresses its concerns and recommendations to the State party in the form of "concluding observations".

${ }^{2}$ UNICEF. Implementation Handbook for the Convention on the Rights of the Child. United Nations Chidren's Fund. 2007. P.305. 
need special protection. As defined by the UN High Commissioner for Refugees (UNHCR), there is increasing preference to call "separated" those children who, though accompanied by an adult, are not with a parent, legal or customary caregiver, but are perhaps with a trafficker, sibling, or acquaintance ${ }^{3}$.

This new enlarged meaning is applied to individual countries. For example, in 2006 the Committee recommended that Thailand "take urgent measures to ensure that the children of migrant workers or their family members, in particular non-registered migrants, are not arbitrarily arrested, detained or persecuted and if they are to be returned to their country of origin, the principle of non-refoulement should be respected. It recommends that the children of migrant workers are guaranteed access to health and social services and to education in accordance with the principle of non-discrimination..."4.

The notion now also covers unaccompanied children departing the country for unknown reasons. Addressing Albania in its Concluding Observations, the Committee noted that "the departure of children from Albania to neighboring countries is a significant problem, and that approximately 4,000 children have left the country unaccompanied by their parents." The Committee recommended that Albania strengthen its efforts in this area, in particular to determine and address the causes of such large-scale departure of unaccompanied children and introduce safeguards to reduce the phenomenon, in particular if such children are victims of illegal networks, and to ensure a coordinated approach to the collection of information and statistics, allowing a response commensurate to the needs." ${ }^{5}$.

The meaning of the notion was deepened further during the same period of time, but by another international body - the European Court of Human Rights (ECtHR). In the case of Mubilanzila Mayeka and Kaniki Mitunga v. Belgium ${ }^{6}$, it ruled that illegal immigrants enjoy the same protection. The applicant in the case, who was only five years old, was held in the same conditions as adults in a closed center even though she was unaccompanied by her parents and no one had been assigned to look after her. No measures were taken to ensure that she received proper counselling and educational assistance from qualified personnel specially mandated for that purpose during two months. The Court considered that the measures taken by the Belgian authorities - informing the first applicant (the mother of the girl who arrived to Belgium together with the child and was separated from her upon the arrival) of the position, giving her a telephone number where she could reach her daughter, appointing a lawyer to assist the second applicant and liaising with the Canadian authorities and the Belgian embassy in Kinshasa - were far from sufficient to fulfill the Belgian State's obligation to provide care for the second applicant. The applicant's position was characterized by her very young age, the fact that she was an illegal immigrant in a foreign land and the fact that she was unaccompanied by her family. She was thus in an extremely vulnerable situation. In view of the absolute nature of the protection afforded by Article 3 of the Convention (prohibition of torture, inhuman and degrading treatment or punishment), noted the Court, it is important to bear in mind that this is the decisive factor and takes precedence over considerations relating to the second applicant's status as an illegal immigrant.

As a result of this case, changes have been made to Belgian law, which now prohibits the detention of unaccompanied child migrants and requires the appointment of a guardian in each

${ }^{3}$ Piwowarczyk L.A. Our Responsibility to Unaccompanied and Separated Children in the United States: a Helping Hand // Public Interest Law Journal, 2006, vol.15, p. 264.

${ }^{4}$ Thailand CRC/C/THA/CO/2, para. 6.

${ }^{5}$ Albania CRC/C/15/Add.249, para. 66-67.

${ }^{6}$ ECtHR, judgment of October 12, 2006. 
case, propelling Belgium from one of the least to one of the most rights-respecting EU states regarding separated and unaccompanied children ${ }^{7}$. The ECtHR's understanding of the nondecisiveness of illegality as a factor for rending protective measures became part of the notion.

Human rights organizations, both international and domestic, as well as academics, have contributed considerably to the construction of the meaning of the term in question. They enriched it by including victims of child-specific persecution like the sale of a child, domestic violence, or social cleansing of street children, fleeing gang membership, sexual orientation, forced labor in the family, suffering a severe disability (autism), or family position in violation of population control in it ${ }^{8}$. The Immigration Law Practitioners Association (UK) authors' simple definition of "separated children" is that these are children who are outside their country of origin and separated from their parents or legal or customary carer. It criticized the practice when children are effectively separated from their parents but are not treated as unaccompanied because they arrive in the UK with someone who is not a parent or primary carer, for example, an older brother, or sister, or an uncle. In addition, though some children appear to be accompanied on their arrival in the UK, the adults with them are not necessarily able or appropriate to assume responsibility for them, nor they are responsible for them in law'.

In 2012 the European Commission supported this broad reading stating in its "Shaping a common approach on unaccompanied minors" memo that:

"Children migrate to the EU for many reasons. Some are asylum seekers fleeing war, armed conflicts, discrimination or persecution in their home countries, sometimes even within their own family, while others are victims of trafficking and slavery. Some dream of education and employment opportunities, others do not leave on their own accord but are sent away by their families to escape poverty. They may arrive clandestinely in an attempt to join relatives, on their own or after having paid smugglers. But whatever the purpose of their journey, they find themselves extremely vulnerable in a foreign country, separated from their loved ones, with rather uncertain prospects.

... each unaccompanied minor must be seen as being a child before being a migrant, and that particular consideration must be given regarding his particular circumstances. As soon as a young person is identified and suspected of being an isolated minor, authorities have to provide immediate protection and care."

\section{What are their rights?}

The consideration of the particular circumstances of the child corresponds to the principle of the best interests of the child assessment- the core principle of CRC and many national jurisdictions.

In spite of the fact that the notion "the best interests of the child" is empty and cannot be defined by law, as it is to be filled in by the facts of a particular case, the international community has made an effort to frame a general understanding of the term ${ }^{10}$. It was necessary as the range and the complexity of situations in which children become separated from families, and the diverse needs of children themselves, make the determination of the best interest of the child a question of paramount importance.

${ }^{7}$ Bhabha J. Arendt's Children: Do Today's Migrant Children Have a Right to Have Rights? // Human Rights Quarterly, 2009, vol.31, p.433.

${ }^{8}$ Piwowarczyk L. Op. cit. P. 266.

${ }^{9}$ Crawley H. Child First, Migrant Second: Ensuring that Every Child Matters. ILPA, 2006. P. 11.

${ }^{10}$ Turkovic K., Grgic A. Best Interests of the Child in the Context of Article 8 of the ECHR /Essays in honour of Dean Spielmann. Oisterwijk, 2015. P. 630. 
International bodies and human rights organization working in the field of protection of unaccompanied and separated children state the best interests of the child constitute the basic standard for guiding decisions and actions taken to help children whether by national or international organizations, courts of law, administrative authorities or legislative bodies ${ }^{11}$. A lot was done to define the process of the best interests' determination (BID). According to the Red Cross Committee, it is a formal process with specific procedural safeguards and documentation requirements that is conducted for certain children of concern, whereby a decision maker is required to weigh and balance all the relevant factors of the particular case, giving appropriate weight to the rights and obligations recognized by the CRC and other human rights instruments, so that a comprehensive decision can be made that best protects the rights of children ${ }^{12}$. It is noted that BID is conducted regarding children for whom tracing was unsuccessful despite extensive (repeated) and comprehensive efforts. It is thus presumed that reunification with families generally qualifies as the best solution for all separated and unaccompanied children ${ }^{13}$.

Setting the guarantees and procedures for the assessment and decision making as a frame for further individualized assessment of personal needs, experts working in the field note the necessity of corresponding state action. In particular they consider it important for the state to clarify that the principle of preferential status of a child's interests demand that in passing legislation, implementing it in practice and in addressing questions that are not regulated by legal acts, a decision or any other action should always be assessed from the perspectives of a child's interests ${ }^{14}$. The basic guiding principles in any child care and protection action are the principle of the "best interests of the child"15 and the principle of non-refoulement.

The drafters of the Convention on the Rights of a Child recognized that the needs of these children would be met if its articles were properly applied to them ${ }^{16}$. The scope of rights attributed to the notion did not change significantly since it was set in the Convention on the Rights of the Child in 1989. In 2005, however, it was deemed important to stress the specific guarantees of this group.

The CRC's General Comment No.6 on "Treatment of unaccompanied and separated children outside their country of origin"17 (2005) set the essential safeguards for such children which should be enforced in domestic legislation, thus forming the unified reading of the notion. It was noted that "it applies to unaccompanied and separated children who find themselves outside of their country of nationality, or, if stateless, outside their country of habitual residence.... irrespective of their residence status, and reasons for being abroad" (para 5).

The General Comment stresses the importance of the information related to the child and his/her family. Among others, facts sought should include: the identity and citizenship of the

${ }^{11}$ International Committee of the Red Cross. Inter-Agency Guiding Principles on Unaccompanied and Separated Children. 2004. P. 17.

${ }^{12}$ International Rescue Committee. Determining the Best Interests of Unaccompanied and Separated Children: Lessons from Guinea. 2007. P. 4.

${ }^{13}$ Ibid. P. 9.

${ }^{14}$ Sipaviciene A., Kules R., Jersovas M. On the Road: Unaccompanied Minors in Lithuania. Geneva, 2009. P. 12.

${ }^{15}$ UNHCR. Guidelines on Policies and Procedures in Dealing with Unaccompanied Minors Seeking Asylum. 1997. P. 5.

${ }^{16}$ UNICEF. Implementation Handbook for the Convention on the Rights of the Child. P. 306.

${ }^{17}$ UN Committee on the Rights of the Child (CRC), General comment No. 6 (2005): Treatment of Unaccompanied and Separated Children Outside their Country of Origin, September 1, 2005, CRC/GC/2005/6. Available at: http://www.refworld.org/docid/42dd174b4.html (accessed: 28.03.2016) 
child and of both parents and siblings; the reason for being separated/unaccompanied; assessment of any vulnerability and needs, and any evidence of persecution, conflict or violence in the country of origin. The state must make all efforts, as quickly as possible, to trace the family of unaccompanied and separated children and reunite them, unless this is contrary the children's interests or would jeopardize the family. If return to the country of origin is not possible due to the risk that the child's rights will be violated, local integration is the primary option. Inter-country adoption may only occur if all efforts regarding tracing and family reunification have failed.

Special attention is paid to the procedural guarantees: interviews and hearings should be conducted in a child-friendly environment, and there should be access to appeal, a guardian or adviser should be appointed to the child to ensure that all decisions taken are in the child's best interests, and, when necessary, lawyers and interpreters.

All children should have access to full educational opportunities, including being registered with school authorities as soon as possible, and being provided with appropriate educational certificates where the return or resettlement is likely. They should have an adequate standard of living and have the same access to health care as children who are nationals.

It is important that a large body of international and regional human rights law providing for and defining the scope of rights of children in question and the responsibilities of the states in this regard is applicable without distinction as to legal status, that is, whether or not someone is legally on the territory ${ }^{18}$.

\section{Unaccompanied and Separated Children in Russia}

Despite the well-defined notion and guarantees attributed, unaccompanied and separated children keep falling between the gaps in many national protection systems. In the case of Russia they lack any specific guarantees.

The ratification of the UN Convention on the Rights of the Child by Russia back in 1990 did not lead to the introduction of the notion in question into the national law. The wording "unaccompanied or separated children" is not mentioned in legal acts related to children or to migrants. But if mentioned, it would be understood and interpreted within the national context of regulation of children's rights.

In accordance with the national law, the obligation to care about the child lies with the parent. A child separated from parents would be labelled "a child left without parental care" (ostavshiysya bez roditelskogo popecheniya). ${ }^{19}$ Two categories of such children include:

- removed from the family due to potential danger to their life and health, or due to the withdrawal of the parental rights of the parent(s); ${ }^{20}$

- abandoned or neglected by their parents ${ }^{21}$ (also called "street children").

${ }^{18}$ Feijen L. The Challenges of Ensuring Protection to Unaccompanied and Separated Children in Composite Laws in Europe // Refugee Survey Quarterly, 2009, vol. 27, p. 66.

${ }^{19}$ Family Code of the Russian Federation. Art. 145.

${ }^{20}$ Article 69 of the Russian Federation Family Code provides reasons for the withdrawal of parental rights, Article 73 (Limitation of parental rights) provides for the right of the court to remove the child from the parent's authority.

${ }^{21}$ According to the Law "On Foundations of the System of Prevention of Underage Vagrancy and Juvenile Delinquency" (1999), a neglected child (beznadzorny rebenok) is a child lacking control following breach or improper execution of duties to care, raise or educate him/her by his parents or other legal caregiver (Art.1); a vagrant child (besprizorny rebenok) is a neglected child with no home. 
Theoretically these children are entitled to all the rights provided for in the Family Code of Russia, including the right to live in a family environment, the right to have access to parents and other relatives, the right to protection, the right to a name and property rights. However, in case such a child is identified, he/she is subject to the scheme of treatment of the "child left without parental care" - the state considers its primary obligation to find a placement best suited to his/her needs. ${ }^{22}$ No specific BID is conducted ${ }^{23}$. In some cases children would be returned home, in others - placed within state child care institutions. ${ }^{24}$ In both cases the decision is taken by the local state care authorities. Absence of caregivers in this situation does not add to the level of the protection of children as it would be if they were to be considered within the international context of the "unaccompanied and separated children" notion. While, for example, in Lithuania (former constituent entity of the USSR, the country-recipient of Russian unaccompanied children) the law distinguishes unaccompanied minors as a separate category of migrants and applies to them general principles of protecting unaccompanied children applied in the $\mathrm{EU}^{25}$, in Russia these children do not obtain any special status with specific guarantees attached. Thus the international law notion is substituted by the Russian one - the literal meaning of which was similar, the presupposed difference in treatment was neglected. The new wording has certain negative connotation (opposite to the "children in need of special protection by the state"; connotation of the notion "unaccompanied or separated children") places all the blame regarding the situation of children on their parents, leaving the state a secondary role.

Practitioners working with unaccompanied or separated children from Moldova point out that measures taken regarding these children are inspired by general attitudes towards migrants. Children of migrants are considered as migrants, separated or unaccompanied children - as vagrant or neglected children of migrants ${ }^{26}$. Labelling unaccompanied or separated children as migrants automatically shifts the focus of the audience from the protection of the vulnerable group to the potential hazards of which it could possibly become a source. Increasingly hostile political context, politicization of asylum and immigration discourses along with the economic crisis and customary anti-migrant sentiments in Russia stimulate negative attitudes towards all migrants including minors. ${ }^{27}$

${ }^{22}$ Family Code of the Russian Federation. Art. 145.

${ }^{23}$ Unaccompanied or separated children are placed into specialized institutions and might be detained there for several weeks for the purpose of personal identification, assessment of the reasons and circumstances for their arrival, and for the consequent return to the country of their permanent residence. Children are not informed about refoulement until the last moment to prevent them from running away. In certain cases children were not informed about it at all, and had little or no understanding of where they were moved and for how long. At the same time, there were instances when the child was granted Russian citizenship immediately after he/she was identified with no efforts spent on search and identification of parents and relatives.

${ }^{24}$ JURIX. Situation of Moldovan Separated and Unaccompanied Children in Moscow and Moscow Region. Moscow, 2011.

${ }^{25}$ Sipaviciene A., Kules R., Jersovas M. Op. cit. P. 5.

26 "After a 'fishing out' of illegal migrant their children were left abandoned" ("Posle 'otlova' nelegalnyh migrantov ih deti okazalis practicheski besprizornikami ”). Available at: http://nazaccent.ru/content/7046-posleotlova-nelegalnyh-migrantov-ih-deti.html (accessed: 30.03.2016)

${ }^{27}$ News repeatedly refer to the results of special operations conducted by the Department of the Interior resulting in identification and prosecution of illegal migrants. They refer to statistics of crimes ("Migrants raids in Moscow: more than 7 thousand arrested within a day"). Available at: http: //www.newsru.com/ russia/25oct2014/migr.html (accessed: 30.03.2016). This influences public opinion. According to recent polls, 35\% of Russians consider migrants to be the main threat to Russia (VTsIOM press issue N 2652 of 19.08.14. 
The State Ombudsperson for the rights of the child in Saint-Petersburg shares the understanding that children belonging to a family of migrants should be considered as migrants first, and children - second. In her talk with human rights activists, she stated that "first and foremost migrant children should comply with the legislation on migrants and a positive decision on admitting or keeping an "illegal child" at school can only be made in exceptional circumstances" 28 . Such attitudes are shared and/or employed by politicians. For example, in 2013 a draft law aimed at the prevention of children of illegal migrants from attending schools and kinder-gardens was introduced by the member of the ruling party "United Russia" (Yedinaya Rossiya ${ }^{29}$. According to the draft law, access to education should only be provided for children of those migrants who prove they are taxpayers in Russia. This measure will allegedly allow the allocation of more places for Russian children.

The question of what scope of rights of separated and unaccompanied children should have or even, whether they should have rights - is typical not only in Russia. Migration authorities, politicians and even some academics ${ }^{30}$ in different countries doubt that these children should have equal access to social services in the host country. They treat migrant minors not as children but as objects of interest for homeland security, border patrols, and immigration discourse ${ }^{31}$. This was addressed by the CoE Commissioner for Human Rights, Thomas Hammerberg, who noted that:

"Decision-making politicians appear sometimes to be confused about how to treat migrant children. On the one hand, they state their full support of the idea that children do have rights and all recognize that our aging continent will need migration, not least young migrants. On the other hand a number of them appear not to be able to draw the necessary conclusions about the rights of migrant children" 32 .

Formulating and passing laws is probably the easiest step in the journey from aspirational principle to practical realization ${ }^{33}$ as it would hardly be possible to implement the rights of a vulnerable group based solely on international standards. However, the statutory text that may seem plain at first glance and consist of "ordinary" words, still needs an interpretation ${ }^{34}$ with

Available at: http://wciom.ru/index.php?id=459\&uid=114941 (accessed: 30.03 .2016 ); 15\% state there are too many migrants in Russia, 14 \% claim "we need to throw them out, we don't need them", $26 \%$ think there are not jobs for ourselves, $12 \%$ say that migrants" "behavior is rude, they do not respect our laws", $8 \%$ agree that "the delinquency among them is high". VTsIOM press issue N 2442 of 30.10.13. Available at: http://wciom.ru/index. php?id=459\&uid=114584 (accessed: 30.03 .2016 ). Experts confirm the anti-migrant feelings are traditional in Russia and a certain decrease in 2014 due to the shift of the propaganda from migrants to Ukraine is only temporary ("Ukraine confused it for nationals: xenophobia and radical nationalism and countering them in Russia in the first half of 2014"). Available at: http://www.sova-center.ru/racism-xenophobia/publications/2014/07/ d29887 (accessed: 30.03.2016)

${ }^{28}$ Anti-Discrimination Centre Memorial. The Situation of Children Belonging to Vulnerable Groups in Russia. Moscow, 2013. P. 11.

29 "There is a suggestion not to accept children of illegal migrants in nurseries." Available at: http://izvestia. ru/news/557658 (accessed: 30.03.2016)

${ }^{30}$ Bhabha J. Op. cit. P. 416.

${ }^{31}$ Piwowarczyk L. Op. cit. P. 263.

${ }^{32}$ Hammerberg T. Address at the Save the Children Sweden Conference. 2007. Available at: https://wcd.coe. int/ViewDoc.jsp?id=1111219 (accessed: 30.03.2016)

${ }^{33}$ Bhabha J. Op. cit. P. 425.

${ }^{34}$ Soboleva A. Use and Misuse of Language in Judicial Decision-Making: Russian Experience // International Journal for the Semiotics of Law, 2013, vol. 26, no 3, p. 3. 
the main principles of the Convention on the Rights of the Child in view. Use in national law of the notion similar to the literal translation of the international law notion with no human rights context behind it allows the state to substitute a meaning by the one suitable for national perceptions (re-define) depriving the group from rights and guarantees.

\section{Deferences}

Bhabha J. (2009) Arendt's Children: Do Today's Migrant Children Have a Right to Have Rights? Human Rights Quarterly, vol. 31, pp. 410-451.

Boziev T.O., Krivosheeva M.A. (2012) Analyz zalonodatelnoy bazy prav detey-sirot, ostavshikhsya bez popechenia roditeley [Analysis of Legal Base of Rights of Orphans Left without Parental Care]. Zhurnal pravovych i ekonomicheskih issledovanyi, no 3, pp. 26-29.

Feijen L. (2009) The Challenges of Ensuring Protection to Unaccompanied and Separated Children in Composite Laws in Europe. Refugee Survey Quarterly, vol. 27, no 4, pp. 63-73.

Il'ina O.Yu. (2015) Semeyno-pravovye prezumptsii interesov rebenka [Family and Legal Presumptions of Child's Interests]. Problema garmonizatsii chastnykh i publichnykh interesov $v$ semeynom prave Rossiyskoy Federatsii [Harmonizing Private and Public Interests in Family Law]. Moscow: YNITI, pp. 72-83.

Kokorina M.S. (2015) Pravovaya priroda ustroistva detey, ostavshikhsya bez popecheniya roditelei, v organizatsii dlya detey-sirot i detey, ostavshikhsya bez popecheniya roditelei [Legal Nature of Adopting Children in Organizations for Orphans] Semeynoe pravo i zakonodatel'stvo: politicheskie i sotsial'nye orientiry sovershenstvovaniya. Tver': Tverskoi universitet, pp.106-110.

Kosova O.Yu. (2015) O primenenii bazisnykh terminov v semeynom zakonodatel'stve [On Applying Basic Terms in Family Law] Semeynoe pravo i zakonodatel'stvo: politicheskie $i$ sotsial'nye orientiry sovershenstvovaniya. Tver': Tverskoi universitet, pp. 115-118.

Krasitskaya L.V. (2012) Osyshestvlenie roditelyami prava na predstavitelstvo I zascitu prav i interesov rebyonka [Fulfilling Parents Rights for Representation and Protection of Child Rights and Interests] /I Ekonomika i pravo, no 3, pp. 116-121.

Krylova O.A. (2009) Neispklneniye obyazannostey po siderzhaniu I vospitaniu nesovershennoletnich detey kak osyjvanie primeneniia mer uridichesloy otvetstvennosti $\mathrm{k}$ roditelyam [Non-Fulfilling Duties in Maintenance and Education of Children as Reason For Legal Responsibility]. Sovremennoye pravo, no 8, pp. 57-62.

Nechaeva A.M. (2016) Pravovye problemy semeynogo vospitaniya nesovershennoletnikh [Legal Issues of Family Education of Non-Adults]. Moscow: Prospekt, 128 p. (in Russian)

Nikonov K. (2007) Pravovye aspecty zaschity detey $v$ voorushennych conflictah [Legal Aspects of Protecting Children during Armed Conflicts] Moskovsky zhurnal mezhdunarodnogo prava, no 4, pp. 216-225.

Piwowarczyk L. (2006) Our Responsibility to Unaccompanied and Separated Children in the United States: a Helping Hand. Public Interest Law Journal, vol. 15, pp. 263-296.

Sipaviciene A., Kules R., Jersovas M. (2009) On the Road: Unaccompanied Minors in Lithuania. Geneva: International Organization for Migration, $54 \mathrm{p}$.

Soboleva A. (2013) Use and Misuse of Language in Judicial Decision-Making: Russian Experience. International Journal for the Semiotics of Law, vol. 26, no 3, pp. 673-692.

Turkovic K., Grgic A. (2015) Best Interests of the Child in the Context of Article 8 of the ECHR / Essays in honor of Dean Spielmann. Oisterwijk: Wolf, 720 p.

Zharova O.N. (2016) Sotsialno-pravovaya zaschita detey-sirot i ostavshikhsya bez popechenia roditeley [Social and Legal Protection of Orphans and Children Left without Parent Care). Molodoy uchenyi, no 8, pp. 745-747. 